\title{
STUDI PENGETAHUAN IBU NIFAS TENTANG TANDA BAHAYA SELAMA MASA NIFAS \\ (Di Desa Pomahan Janggan, Kecamatan Turi, Kabupaten Lamongan 2015)
}

\section{Husnul Muthoharoh*}

\author{
*Dosen Program Studi Diploma III Kebidanan Universitas Islam Lamongan \\ J1 Veteran No 53 A Lamongan
}

\begin{abstract}
ABSTRAK
Masa nifas adalah masa sesudah persalinan dan kelahiran bayi, plasenta, serta selaput yang diperlukan untuk memulihkan kembali organ kandungan seperti sebelum hamil dengan waktu kurang lebih 6 minggu.

Tujuan penelitian ini adalah untuk mengetahui gambaran pengetahuan ibu nifas tentang tanda bahaya selama masa nifas di Desa Pomahan Janggan, Kecamatan Turi, Kabupaten Lamongan.

Metode yang digunakan dalam penelitian ini adalah deskriptif observasional dengan menggunakan teknik pengambilan sampel consecutive sampling. Sampling diambil dari jumlah populasi yaitu 15 ibu nifas dengan menggunakan alat ukur kuesioner.

Hasil penelitian didapatkan masih banyak ibu nifas yang memiliki pengetahuan yang kurang tentang tanda bahaya masa nifas yaitu sebanyak 8 responden. Ibu nifas yang memiliki pengetahuan cukup sebanyak 4 responden dan ibu nifas yang memiliki pengetahuan baik sebanyak 3 responden.

Kesimpulan dari penelitian ini adalah pengetahuan ibu nifas tentang tanda bahaya masa nifas masih kurang.

Dari penelitian diatas diharapkan ibu nifas lebih peka dalam mendeteksi tanda bahaya selama masa nifas. Selain itu bagi petugas kesehatan agar mengoptimalkan perannya sebagai konselor sehingga pengetahuan ibu nifas bisa lebih baik dan bisa mencegah komplikasi selama masa nifas.
\end{abstract}

Kata Kunci : Pengetahuan, ibu nifas, tanda bahaya 


\section{PENDAHULUAN}

\section{Latar Belakang}

Nifas adalah masa sesudah persalinan dan kelahiran bayi, plasenta, serta selaput yang diperlukan untuk memulihkan kembali organ kandungan seperti sebelum hamil dengan waktu kurang lebih 6 minggu (Saleha, 2009).

Masa nifas berlangsung selama kira-kira 6-8 minggu. Setelah melahirkan, ibu masih perlu mendapat perhatian karena ibu nifas masih beresiko mengalami perdarahan atau infeksi yang dapat mengakibatkan kematian ibu. Untuk menjaga kesehatan ibu nifas dan bayi baru lahir baik persalinannya di tolong oleh tenaga kesehatan atau tidak harus mendapat Post Natal Care (pelayanan nifas) oleh tenaga kesehatan (Prawirohardjo, 2005).

Target AKI di Indonesia pada tahun 2015 adalah 102 kematian per 100.000 kelahiran hidup. Sementara itu berdasarkan Survei Demografi dan Kesehatan Indonesia (SDKI) tahun 2012, Angka Kematian Ibu (AKI) (yang berkaitan dengan kehamilan, persalinan, dan nifas) sebesar 359 per 100.000 kelahiran hidup. Angka ini masih cukup jauh dari target yang harus dicapai pada tahun 2015.

AKI juga merupakan salah satu target yang telah ditentukan dalam tujuan pembangunan Millenium Development Goals (MDGs) yang ke-5 yaitu meningkatkan kesehatan ibu dimana target yang akan dicapai sampai tahun 2015 adalah mengurangi sampai 3/4 resiko dari jumlah kematian ibu. Penyebab terbesar kematian ibu yang terjadi pada masa nifas yaitu perdarahan $28 \%$, eklampsi $24 \%$, infeksi $11 \%$, dan lain- lain sebesar $11 \%$ (DepKes RI, 2008).

Masih banyak ibu nifas yang mengalami masalah pada masa nifas yang tidak di ketahui atau terdeteksi oleh tenaga kesehatan. Beberapa faktor yang mempengaruhi pengetahuan pada ibu nifas yaitu pengetahuan (pendidikan, usia, pekerjaan, informasi, pengalaman, lingkungan, sosial ekonomi, sosial budaya) dan juga konseling dari tenaga kesehatan selama kehamilan dan setelah persalinan (Notoadmodjo, 2010).

Tanda bahaya masa nifas adalah suatu tanda abnormal yang mengindikasikan adanya bahaya atau komplikasi yang dapat terjadi selama masa nifas, apabila tidak dilaporkan atau tidak terdeteksi bisa menyebabkan kematian ibu.

Konseling mengenai tanda-tanda bahaya masa nifas sangat penting dan perlu, karena masih banyak ibu atau wanita yang sedang hamil atau pada masa nifas belum mengetahui tentang tanda-tanda bahaya masa nifas, baik yang diakibatkan masuknya kuman ke dalam alat kandungan seperti eksogen (kuman datang dari luar), autogen (kuman masuk dari tempat lain dalam tubuh) dan endogen (dari jalan lahir sendiri) (Mochtar, 2008)

Asuhan pada masa nifas sangat diperlukan dalam periode ini karena masa nifas merupakan masa kritis untuk ibu dan bayinya. Tenaga kesehatan paling sedikit melaksanakan 4 kali kunjungan pada masa nifas. Tujuan kunjungan ini diantaranya yaitu untuk menilai status ibu dan bayinya, melaksanakan screening yang komprehensif, mendeteksi masalah, mengobati atau merujuk bila terjadi komplikasi pada ibu dan bayi. Sehingga diharapkan dengan adanya kunjungan pada ibu nifas, komplikasi yang terjadi pada masa nifas dapat dicegah (Prawirohardjo, 2009).

Apabila ibu nifas mengerti tentang tanda-tanda bahaya masa nifas, maka ibu dapat segera memeriksakan diri ke petugas kesehatan. Sebaliknya, jika ibu tidak mengerti tanda-tanda bahaya masa nifas maka ibu tidak akan 
segera memeriksakan diri kepada petugas kesehatan.

Berdasarkan latar belakang di atas, maka penulis berminat untuk melakukan penelitian tentang "Studi pengetahuan ibu nifas tentang tanda bahaya selama masa nifas".

\section{HASIL DAN PEMBAHASAN}

HASIL

\subsection{Data Umum}

1.1.1. Gambaran Lokasi Penelitian

1. Data Geografi

Desa Pomahan Janggan terletak di Kecamatan Turi Kabupaten Lamongan dengan luas wilayah $57,88 \mathrm{Km}^{2}$, dengan jarak $12 \mathrm{Km}$ dari Ibukota Kabupaten Lamongan, dengan jumlah KK sebanyak 355 KK. Sedangkan batas-batas wilayah adalah sebagai berikut :

1) Sebelah utara : Desa Bojoasri

2) Sebelah timur : Desa Kepudi Bener

3) Sebelah selatan : Desa Bambang

4) Sebelah barat : Desa Kemlagi Lor

Sarana pelayanan kesehatan yang digunakan adalah puskesmas pembantu, polindes, bidan desa dan perawat. Fasilitas jalan yang memadai sehingga proses transportasi ke fasilitas kesehatan sangat mudah.

\subsubsection{Data Demografi}

Jumlah penduduk Desa Pomahan Janggan Kecamatan Turi Kabupaten Lamongan adalah

1) Jumlah penduduk

1.966 jiwa

2) Jumlah Penduduk laki-laki

934 jiwa

3) Jumlah Penduduk Perempuan : 1032 jiwa

2. Fasilitas Umum

1) Sarana Peribadatan

(1) Masjid : 3 buah

(2) Musholla : 7 buah

2) Sarana pendidikan
1) $\mathrm{TK}$
$: 2$ buah
2) $\mathrm{SD}$
: 2 buah

3) SMP :2 buah

4) MA : 1 buah

3. Fasilitas Pelayanan Kesehatan

1) Polindes : 1 buah

2) Posyandu : 3 buah

3) Tempat dokter praktek : -

4) Dokter umum :-

5) Dokter gigi :-

6) Perawat :2 orang

7) Bidan :2 orang

1.1.3. Karakteristik Responden

1) Umur

Tabel 2.1 Distribusi Responden berdasarkan umur di Desa Pomahan Janggan Kecamatan Turi Kabupaten Lamongan

\begin{tabular}{|c|c|c|c|}
\hline No. & Umur & $\mathrm{N}$ & $\%$ \\
\hline 1. & $\leq 20$ & 10 & $66,7 \%$ \\
2. & $21-35$ & 3 & $20 \%$ \\
3. & $>35$ & 2 & $13,3 \%$ \\
\hline \multicolumn{2}{|c|}{ Total } & 15 & $100 \%$ \\
\hline
\end{tabular}

Dari tabel 2.1 di atas diketahui sebagian besar responden berumur $\leq 20$ tahun yaitu $(66,7 \%)$ responden dan sebagian kecil responden berumur > 35 tahun yaitu $(13,3 \%)$ responden

2) Pendidikan

Tabel 2.2 Distribusi responden berdasarkan pendidikan di Desa Pomahan Janggan Kecamatan Turi Kabupaten Lamongan

\begin{tabular}{|c|l|c|c|}
\hline No. & Pendidikan & $\mathrm{N}$ & $\%$ \\
\hline 1. & SD & 3 & $20 \%$ \\
2. & SMA & 12 & $80 \%$ \\
3. & PT & 0 & $0 \%$ \\
\hline \multicolumn{2}{|l|}{ Total } & 15 & $100 \%$ \\
\hline
\end{tabular}

Dari tabel 2.2 di atas diketahui sebagian besar responden berpendidikan 
Menengah yaitu 12 (80\%) responden dan sebagian kecil berpendidikan rendah $3(20 \%)$ responden.

3) Pengalaman

Tabel 2.3 Distribusi responden berdasarkan Pengalaman di Desa Pomahan Janggan Kecamatan Turi Kabupaten Lamongan

\begin{tabular}{|c|l|c|c|}
\hline No & \multicolumn{1}{|c|}{ Pengalaman } & $\mathrm{N}$ & $\%$ \\
\hline 1. & 1 kali melahirkan & 11 & $73,3 \%$ \\
2. & 2 kali melahirkan & 1 & $06,7 \%$ \\
3. & $\begin{array}{l}\text { > kali } \\
\text { melahirkan }\end{array}$ & 3 & $20 \%$ \\
\hline \multicolumn{2}{|c|}{ Total } & 15 & $100 \%$ \\
\hline
\end{tabular}

Dari tabel 2.3 di atas diketahui sebagian besar responden melahirkan 1 kali/pertama yaitu $11 \quad(73,3 \%)$ responden dan sebagian kecil pernah melahirkan 2 kali yaitu $1 \quad(06,7 \%)$ responden.

\subsection{Data Khusus}

1.2.1.Pengetahuan Ibu nifas tentang tanda bahaya selama masa nifas

Tabel 2.4 Distribusi pengetahuan ibu nifas tentang tanda bahaya selama masa nifas di Desa Pomahan Janggan Kecamatan Turi Kabupaten Lamongan

\begin{tabular}{|c|l|c|c|}
\hline No. & Pengetahuan & N & $\%$ \\
\hline 1. & Baik & 3 & $20, \%$ \\
2. & Cukup & 4 & $26,7 \%$ \\
3. & Kurang & 8 & $53,3 \%$ \\
\hline \multicolumn{2}{|c|}{ Total } & 15 & $100 \%$ \\
\hline
\end{tabular}

Dari tabel 2.4 di atas diketahui responden berpengetahuan kurang yaitu sebanyak 8 responden $\quad(53,3 \%)$ responden, ibu nifas yang memiliki pengetahuan cukup sebanyak 4 responden $(26,7 \%)$, dan ibu nifas yang berpengetahuan baik yaitu sebanyak 3 respnden $(20 \%)$.

\section{PEMBAHASAN}

Dari hasil pengumpulan data, distribusi responden berdasarkan umur seperti pada tabel 2.1 di dapatkan sebagian besar responden berumur $\leq 20$ tahun, yaitu sebanyak $10 \mathrm{ibu}$ nifas $(66,7 \%)$.

Menurut Elizabeth yang di kutip oleh Nursalam (2003), usia adalah umur individu yang terhitung mulai saat di lahirkan sampai saat berulang tahun, semakin cukup umur, tingkat kematangan dan kekuatan seseorang akan lebih matang dalam berfikir dan bekerja.

Hal itu selaras dengan pernyataan dari Long yang di kutip oleh Nursalam (2003), makin tua umur seseorang, makin konstruktif dalam menghadapi masalah yang di hadapi.

Semakin banyak umur atau semakin tua seseorang maka akan mempunyai kesempatan dan waktu yang lebih lama dalam mendapatkan informasi dan pengetahuan. Dengan demikian, semakin tua umur responden maka tingkat pengetahuan ibu nifas tentang tanda-tanda bahaya masa nifas semakin baik.

Dari hasil pengumpulan data distribusi responden menurut pendidikan, seperti pada tabel 5.2 didapatkan bahwa sebagian besar responden tingkat pendidikannya menengah yaitu sebanyak 12 ibu nifas (80\%).

Menurut Koentjaraningrat yang dikutip oleh Nursalam (2003), bahwa makin tinggi pendidikan seseorang, maka makin mudah menerima informasi sehingga makin banyak pula pengetahuan yang dimiliki. Responden 
yang berpendidikan tinggi akan mudah menyerap informasi, sehingga ilmu pengetahuan yang dimiliki lebih tinggi namun sebaliknya orang tua yang berpendidikan rendah akan mengalami hambatan dalam penyerapan informasi sehingga ilmu yang dimiliki juga lebih rendah yang berdampak pada kehidupannya.

Hal tersebut juga disebabkan oleh faktor pengalaman. Dari tabel 5.3 hampir sebagian ibu nifas baru pertama kali melahirkan yaitu sebanyak 11 orang $(73,3 \%)$,

Menurut Notoadmodjo (2010) pengalaman merupakan suatu cara untuk memperoleh kebenaran pengetahuan. Pengalaman dapat menuntun seseorang untuk menarik kesimpulan dengan benar, sehingga dari pengalaman yang benar di perlukan berfikir yang logis dan kritis.

Hal ini membuktikan bahwa umur, pendidikan dan pengalaman sangat berpengaruh terhadap pengetahuan seseorang dimana semakin tua umur seseorang semakin banyak pengetahuan yang di miliki, semakin tinggi pendidikan semakin banyak pengetahuan yang di dapat dan juga semakin sering pengalaman ibu melahirkan semakin banyak pengetahuan yang di peroleh tentang tanda bahaya selama masa nifas.

\section{KESIMPULAN}

Setelah menganalisis data dan melihat hasil pembahasan maka peneliti dapat mengambil kesimpulan:

1. Umur, pendidikan dan pengalaman sangat berpengaruh terhadap pengetahuan seseorang dimana semakin tua umur seseorang semakin banyak pengetahuan yang di miliki, semakin tinggi pendidikan semakin banyak pengetahuan yang di dapat dan juga semakin sering pengalaman ibu melahirkan semakin banyak pengetahuan yang di peroleh tentang tanda bahaya selama masa nifas.

2. Pengetahuan ibu nifas tentang bahaya masa nifas masih kurang

\section{DAFTAR PUSTAKA}

Depkes R.I. 2008. Profil Kesehatan Indonesia. Jakarta: Depkes RI

Mochtar, Rustam, Sinopsis Obstetri. Edisi 2. Jilid 1. Jakarta: Buku Kedokteran EGC. 2008

Notoatmodjo,S. 2010. Ilmu Perilaku Kesehatan. Jakarta : PT Rineka Cipta

Notoatmodjo,S. 2010. Metodologi Penelitian Kesehatan. Jakarta: PT Rineka Cipta.

Nursalam, 2003. Konsep dan Penerapan Metodologi Penelitian Ilmu Keperawatan: Pedoman Skripsi, Tesis dan instrument Penelitian. Jakarta: Salemba Medika

Prawirohardjo, Sarwono., 2005. Ilmu kebidanan. Jakarta : Yayasan Bina Pustaka.

Prawirohardjo, Sarwono. 2009. Pelayanan Kesehatan Maternal dan Neonatal. Jakarta: PT Bina Pustaka

Pusdiknakes. 2003. Asuhan Antenatal. Jakarta: Pusdiknakes

Saleha, Siti. 2009. Asuhan Kebidanan Pada Masa Nifas. Jakarta: Salemba Medika 